\title{
Fear of COVID-19 and Positivity: Mediating Role of Intolerance of Uncertainty, Depression, Anxiety, and Stress
}

\author{
Fuad Bakioğlu ${ }^{1} \cdot$ Ozan Korkmaz $^{2}$ (D) Hülya Ercan ${ }^{1}$ \\ Published online: 28 May 2020 \\ (C) Springer Science+Business Media, LLC, part of Springer Nature 2020
}

\begin{abstract}
This study aimed to investigate the mediating role of intolerance of uncertainty, depression, anxiety, and stress in the relationship between the fear of COVID-19 and positivity. The participantsconsisted of 960 individuals, including 663 females(69.1\%)and 297 males(30.9\%). Theage of the participants ranged between 18 and $76(29.74 \pm 9.64)$. As aresult of the correlationanalysis, a positive relationship was found between fear of COVID-19 and intolerance of uncertainty, depression, anxiety, and stress, and a negative relationship was determined between the fear of COVID-19 and positivity. The result of the analysis for the study model indicated that there was a mediating role of intolerance of uncertainty, depression, anxiety, and stress in the relationship between the fear ofCOVID-19 and positivity. Eliminating uncertainty from the fear ofCOVID-19 will contribute to reducing depression, anxiety and stress, and increasing positivity.
\end{abstract}

Keywords Fear of COVID-19 · Intolerance of uncertainty $\cdot$ Depression · Anxiety $\cdot$ Stress · Positivity

\section{Introduction}

In December 2019, a new type of coronavirus disease called COVID-19 was determined to be the cause of an epidemic in the Wuhan region of China (World Health Organization/WHO

Ozan Korkmaz

pd.ozankorkmaz@gmail.com

Fuad Bakioğlu

fuadpdr@gmail.com

Hülya Ercan

ehulya@kmu.edu.tr

1 Faculty of Education, Karamanoglu Mehmetbey University, 70100 Karaman, Turkey

2 Psychological Counseling and Guidance Application and Research Center, Karamanoglu Mehmetbey University, 70100 Karaman, Turkey 
2020a). WHO declared COVID-19 as a pandemic by reporting that more than 8000 deaths had occurred in 159 countries as of 18 March 2020 (WHO 2020b). WHO explained the mortality rate in COVID-19 transmission as 2\% (WHO 2020c), and then updated this rate as $3.4 \%$ (WHO 2020d). In Turkey, the first cases were announced on 10 March 2020. In the following period, the number of cases approached 150,000, and the number of those who lost their lives reached 4000 (T. R. Ministry of Health 2020).

Various measures taken in different countries to prevent the spread of the outbreak have led to increased panic and stress in individuals. In some countries, people have begun to stock up on groceries, and they have even started owning guns (BBC 2020). We have also heard the news of people from the US, Turkey, Italy, and France committing suicide due to the fear of COVID-19 (Ahaber 2020; Euronews 2020a, b; WSWS 2020). At the initial stage of the pandemic, experts explained ways to protect physical health. As the disease has spread, they have begun to emphasize the importance of maintaining mental health, as well.

Individual, national, and international level effects of the COVID-19 pandemic are expected (Pakpour and Griffiths 2020). The outbreak can be said to trigger feelings of helplessness, sickness, and death at the individual level. Fear is generally a primitive feeling and arises in the face of a real or perceived threat. This feeling is for the present, as it involves producing a response to something that is believed to be threatening. Some physiological symptoms such as an increase in pulse, muscles stiffness, and acceleration of breathing in the event of fear prepare the body to produce a response when in danger. On the other hand, fear also causes some changes in the cognitive system such as attention levels (Dozois et al. 2019). Therefore, the fear of COVID-19 can be thought to have the potential to affect positivity levels of individuals.

Positivity is one of the concepts addressed in the positive psychology movement. The attempt to include positivity in psychology was initiated by Martin Seligman, the President of the American Psychological Association (APA) (Seligman and Csikszentmihalyi 2000). Until then, as Abraham Maslow had warned half a century ago, the science of psychology had become successful in the negative domain rather than the positive domain, in a sense, restricting its rightful jurisdiction to only the darker half of psychology (Maslow 1954). For example, Diener et al. (1999) found that the proportion of studies investigating positive psychological states to those studying negative psychological states was $1 / 17$. This demonstrated that a disease model predominated in health research despite the definition stated by the WHO that "Health is not only the absence of disease and disability, but also physical, mental, and social well-being" (WHO 1948). Besides the belief that positive cognitive contents are important for happiness but not important for eliminating or reducing psychological disorders, seeing positive and negative thinking as the opposite ends of a single continuum may be among the reasons for focusing on the negative in psychology. However, this one-dimensional view of the positive and negative aspects of experience is likely to be misleading (MacLeod and Moore 2000; Wood and Johnson 2016). In line with this perspective, the main emphasis of positive psychology can be said to require dealing with the positive in addition to the negative in the field of psychology.

McGrath (2004) stated that positivity was a concept that reflected an optimistic or positive attitude or an emotional state. According to her, positivity is a kind of attitude that includes thoughts, words, and images that help growth, development, and success. Negativity, on the other hand, consists of content that implies criticism or unworthiness of self. People who think negatively think things will not go as planned, and they expect bad outcomes. Therefore, people who think negatively cannot cope with daily stress factors, and they are more likely to develop psychological and physical health problems. Those who believe that they can achieve 
the results they want will continue to strive, even if it is slow or difficult, whereas those who think that they cannot achieve what they want will give up striving and move away from their goals (Scheier and Carver 1992, 1993). Thus, people's expectations form the basis for resorting to one of two very different forms of behavior: thinking positively and continuing to strive or thinking negatively and giving up.

Fredrickson (2009) stated that positivity made individuals feel good, changed the way the mind worked, transformed the future, and restrained negativity. According to her, positivity offers individuals the opportunity to step into the next level of existence; it opens the mind and contributes to the process of building a good future. Being positive can uniquely enliven the worldview, mental energies, relationships, and potentials of individuals.

Positive and negative affect are two basic dimensions that define long-term emotional experiences. While individuals with high levels of positivity tend to be cheerful, enthusiastic, energetic, confident, and alert, those with low levels of positivity tend to exhibit opposite traits. Positivity is a moderately stable feature that remains partially constant over time, and individuals report relatively consistent levels when it comes to different circumstances, such as being alone, interacting with others, or working. Additionally, positivity is a feature that can be developed (Naragon and Watson 2009). When positivity is taken as a positive feature, and it is accepted that it can be developed, it can be thought that some factors might affect positivity negatively, as well. When positivity is positively affected, adaptation to life becomes easier; on the other hand, when it is negatively affected, adaptation to life will become more difficult and it will be challenging to cope with adversity. Intolerance of uncertainty, depression, anxiety, and stress can be considered among factors that negatively affect positivity (Satici et al. 2020a).

Intolerance of uncertainty has been defined as the tendency of an individual to refuse to admit that something negative, though unlikely, might occur (Dugas et al. 2001). Given that many aspects of life are full of uncertainties, it is expected that intolerance of uncertainty will be very challenging for individuals. Buhr and Dugas (2002) determined that there were four dimensions of intolerance of uncertainty. The first of these dimensions is that uncertainty causes feelings of inability to take action; second, uncertainty is stressful and upsetting; third, unexpected events will be negative and should be avoided; and fourth, the uncertainty of the future is unjust. In their study investigating sensitivity to anxiety and intolerance of uncertainty, Carleton et al. (2007), on the other hand, found that the two structures were correlated but independent from each other. Another finding of this study was that the intolerance of uncertainty had two dimensions, including prospective anxiety and inhibitory anxiety. In this case, the intolerance of uncertainty is a structure related to fear and anxiety, but it can also be a component of destructive and false evaluations and it can affect positivity (Satici et al. 2020b).

Depression is another variable that is thought to be related to positivity. Depression leads to symptoms related to the emotional domain such as sadness, misery, decreased attention and desire, not enjoying the activities and life that were previously liked; psychomotor symptoms such as slowing, fatigue, and agitation; cognitive symptoms such as feelings of guilt, pessimism, inadequacy, worthlessness, and the thought of death; and vegetative symptoms such as disruption in sleep and appetite and sexual aversion (Efilti 2018). All these symptoms can seriously impair individuals' adaptation to daily life. Depression, which can be seen in any age group and is referred to as the common cold of psychiatry due to its prevalence, can be examined in several groups. Severe symptoms of two weeks or more are referred to as major depressive disorder. In this disorder, individuals may feel completely worthless or overly guilty and may want to harm themselves. Major depressive disorder can physically affect a person by disrupting sleep, appetite, and sexual drive (APA 2013; Beidel et al. 2014; Nolen-Hoeksema 2014). 
Anxiety is the natural warning system of the body indicating the imminent danger and corrective action to be taken (Hooley et al. 2016). Anxiety is a future response and often shows up when people face a new situation or when there are some significant changes in their lives. Increased number of heartbeats, sweating, feeling of tension, and the thought that something undesirable will happen are common symptoms of anxiety. In most cases, the symptoms that emerge are time-limited and disappear when the event ends (Beidel et al. 2014). However, individuals with anxiety disorders experience extreme fear and/or anxiety, and this often leads to a discordant avoidance model (Dozois and Rnic 2019).

Stress can be defined as any negative emotional experience accompanied by biochemical, physiological, cognitive, and behavioral responses. However, the causes of stress and accompanying symptoms vary greatly. Stress can occur as a result of physical causes (a medical illness or physical injury), environmental causes (natural disaster, high noise level, changes in life status), interpersonal-social causes (broken relationships, arguing with family members) or psychological causes (sudden occurrences such as taking the final test tomorrow instead of the next day) (Beidel et al. 2014). Additionally, if the events are uncontrollable, unpredictable, or perceived as uncertain and associated with a large part of life such as parenting, personal relationships, or success, the risk of stress increases (Taylor 2006). Stress does not always lead to negative consequences and basically serves to promote adaptation. However, the level of stress is very important. In difficult life events, low stress makes it easier to cope, while high stress can cause the opposite; it can even lead to physical and psychological problems.

The COVID-19 pandemic is likely to threaten people's physical health and lives, as well as increasing their stress levels and triggering a wide range of psychological problems such as anxiety and depression (Harper et al. 2020; Pakpour and Griffiths 2020; Taylor et al. 2020). The addition of mental health problems to the physical health problems caused by the pandemic will substantially worsen the situation. Research into this issue can be said to be vital in order for specialists to prepare for possible mental health problems. However, since the epidemic has shown up relatively recently and progressed rapidly, the number of studies published on the topic is quite limited. Indeed, a small number of studies already published have been conducted mostly in China and some other Far Eastern countries (Huang and Zhao 2020; Lu et al. 2020; Wang et al. 2020).

This study aimed to investigate the mediating role of intolerance of uncertainty, depression, anxiety, and stress in the relationship between the fear of COVID-19 and positivity. Accordingly, the findings obtained from the research were thought to both contribute to the understanding of the relationships between the fear of COVID-19 and the variables in question as well as helping health professionals develop and implement mental health intervention programs to protect the psychological well-being of society in the face of the COVID-19 pandemic. The hypothetical model of the research is presented in Fig. 1.

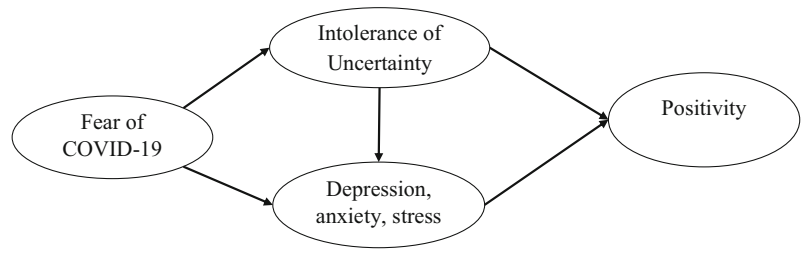

Fig. 1 The hypothesized structural model 


\section{Method}

\section{Participants}

The sample of this study consisted of 960 individuals, including 663 (69.1\%) females and 297 (30.9\%) males. The age of the participants ranged between 18 and $76(29.74 \mathrm{SD}=9.64)$. Of the participants, $29(3.0 \%)$ were primary school graduates, $62(6.5 \%)$ were high school graduates, $55(5.7 \%)$ had an associate degree, $631(65.7 \%)$ an undergraduate degree, and $183(19.1 \%)$ a graduate degree. Additionally, $360(37.5 \%)$ of the participants were found to live in a metropolis, $352(36.7 \%)$ in a province, $185(19.3 \%)$ in a county, and $61(6.4 \%)$ in a town or village.

\section{Data Collection Tools}

The Fear of COVID-19 Scale (FCV-19S) The scale was developed by Ahorsu et al. (2020) and adapted to the Turkish context within the scope of this study. It is a unidimensional scale with seven items. It has a 5-point Likert-type rating system (ranging from 1: Strongly disagree to 5: Strongly agree). Item factor loads of the original scale range from .66 to .74 and item-total correlations vary between .47 and .56. Cronbach's alpha internal consistency coefficient of the scale is .82. A positive and significant correlation was found between the total score of the scale and depression $(\mathrm{r}=.43)$, anxiety $(\mathrm{r}=.51)$, perceived infectability $(\mathrm{r}=.48)$, and germ aversion $(\mathrm{r}=.46)$.

The public domain FCV-19S was adapted to Turkish in this study. Then, the EnglishTurkish translation of the scale was carried out by three field experts, and back translation was performed by two field experts. The final evaluation of the scale was conducted by three field experts, and a final implementation form was created. In the adaptation of the scale to Turkish, the confirmatory factor analysis (CFA) and the item analysis were conducted, and Cronbach's alpha internal consistency coefficient was calculated. As a result of the CFA, goodness of fit indices were found to be at a good level $\left(\chi^{2}=22.08, \mathrm{sd}=9, p<.001 ; \chi^{2} / \mathrm{sd}=2.45\right.$; RMSEA = .03 ; $\mathrm{CFI}=.99$; IFI = .99; $\mathrm{GFI}=.99 ; \mathrm{AGFI}=.99 ; \mathrm{NFI}=.99 ; \mathrm{TLI}=.99 ; \mathrm{RFI}=.99 ; \mathrm{SRMR}=$ $.014)$. The factor load values of the items were determined to vary between .73 and .82 . The eigenvalue of the one-dimensional and 7-item scale was 4.12, and the total explained variance was $58.86 \%$. The corrected item-total correlations of the scale items were found to range from .62 to .72 , and Cronbach's alpha internal consistency coefficient was determined as .88 .

The adaptation of the FCV-19S to Turkish was also carried out by other researchers (Satici et al. 2020a). The validation had not yet been published while the present study was being conducted. However, when the values of this study and Satici et al. (2020a) were compared, it was observed that similar results were obtained. Additionally, the FCV-19S was confirmed in Bangla (Sakib et al. 2020), Italy (Soraci et al. 2020), and Eastern Europe (Reznik et al. 2020) versions.

The Positivity Scale (PS) This scale, which was developed by Caprara et al. (2012), was adapted to the Turkish context by Çıkrıkçı et al. (2015). It is a unidimensional scale with eight items and has a 5-point Likert-type scoring structure (ranging between 1: Not appropriate at all and 5: Completely appropriate). The high scores obtained from the scale indicate high levels of positivity. Cronbach's alpha internal consistency coefficient of the scale is .73, and the test- 
retest coefficient is .91. For the present study, Cronbach's alpha internal consistency coefficient of the Positivity Scale was calculated as .85 .

The Intolerance of Uncertainty Scale (IUS-12) This scale was developed by Carleton et al. (2007) and adapted to the Turkish context by Sarıçam et al. (2014). It is made up of two dimensions (prospective anxiety, inhibitory anxiety) and 12 items. It is also a 5-point Likerttype scale (ranging from 1: Not at all characteristic of me to 5: Entirely characteristic of me). It is possible to calculate the overall score of the scale, as well as calculating the total scores of the sub-dimensions. The high scores obtained from the scale indicate that the individual has a high intolerance of uncertainty. Cronbach's alpha internal consistency coefficient of the scale was calculated as $.84, .77$, and .88 for prospective anxiety and inhibitory anxiety subdimensions, and overall scale, respectively. In addition, the test-retest coefficient for the overall scale was found as .74. Cronbach's alpha internal consistency coefficients for prospective anxiety, inhibitory anxiety sub-dimensions, and overall scale were calculated as .80, .90, and .89 , respectively.

Depression, Anxiety, and Stress Scale (DAS-21) This scale was developed by Lovibond and Lovibond (1995). The scale was found to have three different Turkish adaptation studies. The first was conducted by Yilmaz et al. (2017) in 2017, the second by Sarıçam (2018) in 2018, and the third by Yildırım et al. (2018) in 2018. In this study, the adaptation of Yildırım et al. (2018) was employed. The scale consists of 21 items, three sub-dimensions (depression, anxiety, and stress) and a 4-point Likert-type scoring system (ranging between 0: Never and 3: Always). By summing the scores of the items obtained from the sub-dimensions, the total score of each sub-dimension is calculated. High scores obtained from the sub-dimensions mean that the emotions of the individual for the related sub-dimension are intense. For depression, anxiety, and stress sub-dimensions, Cronbach's alpha internal consistency coefficients are $.89, .87$, and .90 , and test-retest coefficients are $.93, .83$, and .82 , respectively. For this study, Cronbach's alpha internal consistency coefficients for depression, anxiety, and stress sub-dimensions were calculated as $.88, .85$, and .88 , respectively.

The Personal Information Form This form was used to collect the demographic information of the participants. To collect data, participants were asked questions about their gender, age, education level, place of residence, and whether they have any chronic diseases.

\section{Data Collection and Analysis}

The data of the study were collected from volunteers through an online questionnaire (Google form between March and April 2020). All procedures conducted were approved by the Ethics Committee of Karamanoglu Mehmetbey University (95728670-050.01.02-E.9853). It took an average of 15 to $20 \mathrm{~min}$ to respond to the questionnaire. No personal information was requested from the participants while responding to the questionnaire.

While doing the analyses, normal distribution assumptions were checked. Seeing that the data were normally distributed, the independent samples t-test, one-way analysis of variance (ANOVA), and Pearson's correlation analysis were performed. The structural equation model was used to test the research model. We tested the structural model using maximum likelihood estimation. Several goodness of fit indices were used as criteria for the selection of the above 
model. We used $\chi 2 / \mathrm{df}<5$, GFI, CFI, NFI, TLI, $>.90$, SRMR, and RMSEA $<.08$ as the assessment standards of the model fit index (Hu and Bentler 1999; Tabachnick and Fidell 2007). We performed bootstrapping tests of mediation to examine whether intolerance of uncertainty, depression, anxiety, and stress mediated the relationship between the fear of COVID-19 and positivity (Preacher and Hayes 2008). The Bootstrapping Confidence interval was estimated to reveal the indirect impact of Fear of COVID-19 on positivity; 10,000 resampling and $95 \%$ confidence intervals were used in this process. Confidence intervals that do not contain zero indicate effects that are significant at .05. IBM SPSS Statistics 22.0 and AMOS Graphics 23 software packages were used for the analysis of the study data.

\section{Results}

\section{Descriptive Statistics}

Information about the descriptive features of the study participants is presented in Table 1. The results of the analysis of the fear of COVID-19 were found to be significantly different in favor of women $\left(t_{(960)}=9.33, p<.001\right)$. Additionally, the fear of COVID-19 was determined to be significantly different according to the participants' chronic illness $\left(t_{(960)}=-3.67, \mathrm{p}<.001\right)$. On the other hand, the fear of COVID-19 was found to not differ significantly according to age, level of education, place of residence, and whether the participant had relatives infected with COVID-19.

\section{Correlation Analysis}

Pearson's correlation values were calculated to determine the relationships between the variables of the study. Pearson's correlation values for variables are presented in Table 2.

As seen in Table 2, the correlation between the variables were as follows: a negative and significant correlation between the fear of COVID-19 and positivity $(\mathrm{r}=-.23, p<.01)$, and a positive and significant correlation between prospective anxiety $(\mathrm{r}=.31, \mathrm{p}<.01)$, inhibitory anxiety $(\mathrm{r}=.32, \mathrm{p}<.01)$, depression $(\mathrm{r}=.45, \mathrm{p}<.01)$, anxiety $(\mathrm{r}=.62, \mathrm{p}<.01)$, and stress $(\mathrm{r}=.59, \mathrm{p}<.01)$. Moreover, a negative and significant correlation was found between positivity and prospective anxiety $(\mathrm{r}=-.18, \mathrm{p}<.01)$, inhibitory anxiety $(\mathrm{r}=-.38, \mathrm{p}<.01)$, depression $(\mathrm{r}=-.60, \mathrm{p}<.01)$, anxiety $(\mathrm{r}=-.34, \mathrm{p}<.01)$, and stress $(\mathrm{r}=-.44, \mathrm{p}<.01)$.

\section{Findings of the Research Model}

The correlation between the variables of the study was observed to be significant. At this stage, we analyzed the mediating role of intolerance of uncertainty (prospective anxiety, inhibitory anxiety) and DAS (depression, anxiety, and stress) regarding the extent to which the fear of COVID-19 predicted the positivity. The research model is presented in Fig. 2.

The goodness of fit indices of the study mediation model were found to be significant $(\chi 2$ $(153, N=960)=757.46 ; p<.001 ; \chi 2 / \mathrm{df}=4.95 ; \mathrm{GFI}=.93 ; \mathrm{CFU}=.94 ; \mathrm{NFI}=.93 ; \mathrm{TLI}=.93$; $\mathrm{SRMR}=.062 ; \mathrm{RMSEA}=.06)$.

When the direct effects in the study model were examined, the coefficient values in the explanation of the positivity $(\beta=-.27, p<.01)$, intolerance of uncertainty $(\beta=.35, \mathrm{p}<.01)$, and DAS $(\beta=.56, \mathrm{p}<.01)$ by the fear of COVID-19 were found to be significant. In addition, 
Table 1 Descriptive statistics

\begin{tabular}{|c|c|c|c|c|}
\hline & $f$ & $\%$ & $M$ & $S D$ \\
\hline \multicolumn{5}{|l|}{ Gender } \\
\hline Female & 663 & 69.1 & 20.61 & 5.85 \\
\hline Male & 297 & 30.9 & 16.82 & 5.75 \\
\hline \multicolumn{5}{|l|}{ Age (years) } \\
\hline $18-29$ & 543 & 56.6 & 19.23 & 6.03 \\
\hline $30-39$ & 274 & 28.5 & 19.80 & 6.32 \\
\hline $40-75$ & 143 & 14.9 & 19.53 & 5.76 \\
\hline \multicolumn{5}{|l|}{ Educational level } \\
\hline Primary education & 29 & 3.0 & 21.55 & 6.75 \\
\hline High school & 62 & 6.5 & 19.31 & 6.29 \\
\hline Associate & 55 & 5.7 & 19.60 & 6.19 \\
\hline Undergraduate & 631 & 65.7 & 19.42 & 5.92 \\
\hline Graduate & 183 & 19.1 & 19.15 & 6.39 \\
\hline \multicolumn{5}{|l|}{ Place of residence } \\
\hline Metropolis & 360 & 37.5 & 19.36 & 5.99 \\
\hline Province & 352 & 36.7 & 19.08 & 6.29 \\
\hline County & 185 & 19.3 & 20.09 & 5.78 \\
\hline Town/village & 61 & 6.4 & 20.03 & 6.18 \\
\hline \multicolumn{5}{|l|}{ Chronic illness status } \\
\hline Yes & 119 & 12.4 & 21.34 & 6.02 \\
\hline No & 841 & 87.6 & 19.17 & 6.02 \\
\hline \multicolumn{5}{|c|}{ Relatives with COVID-19 infection } \\
\hline Yes & 41 & 4.3 & 19.51 & 6.53 \\
\hline No & 919 & 95.7 & 19.43 & 6.06 \\
\hline
\end{tabular}

the indirect effect of the fear of COVID-19 in predicting positivity through the mediation of intolerance of uncertainty and DAS in the model was found to be significant $(\beta=-.48, p$ $<.01$ ).

Bootstrapping analysis was performed to determine whether the predictive coefficients obtained in the research model were significant. While performing this analysis, $95 \%$ confidence interval and 10,000 resampling paths were preferred. The results related to the bootstrapping analysis are presented in Table 3.

As seen in Table 3, direct and indirect effects and all path coefficients were found to be significant. Additionally, the range of lower and upper limit values was not zero and all of these results were significant.

Table 2 Information about the relationships between variables

\begin{tabular}{|c|c|c|c|c|c|c|c|c|}
\hline & $M \pm S D$ & 1 & 2 & 3 & 4 & 5 & 6 & 7 \\
\hline 1. Fear of COVID-19 & $19.44 \pm 6.07$ & & & & & & & \\
\hline 2. Positivity & $28.35 \pm 5.74$ & $-.23 * *$ & & & & & & \\
\hline 3. Prospective anxiety & $23.88 \pm 5.15$ & $.31 * *$ & $-.18 * *$ & & & & & \\
\hline 4. Inhibitory anxiety & $16.03 \pm 5.13$ & $.32 * *$ & $-.38 * *$ & $.67 * *$ & & & & \\
\hline 5. Depression & $6.26 \pm 4.53$ & $.45 * *$ & $-.60 * *$ & $.37 * *$ & $.51 * *$ & & & \\
\hline 6. Anxiety & $3.34 \pm 3.37$ & $.62 * *$ & $-.34 * *$ & $.35 * *$ & $.40^{* *}$ & $.68 * *$ & & \\
\hline 7. Stress & $5.99 \pm 4.21$ & $.59 * *$ & $-.44 * *$ & $.40 * *$ & $.40 * *$ & $.48 * *$ & $.81 * *$ & $.80 * *$ \\
\hline
\end{tabular}

$* * \mathrm{p}<.01 ; M$, mean; $S D$, standard deviation 


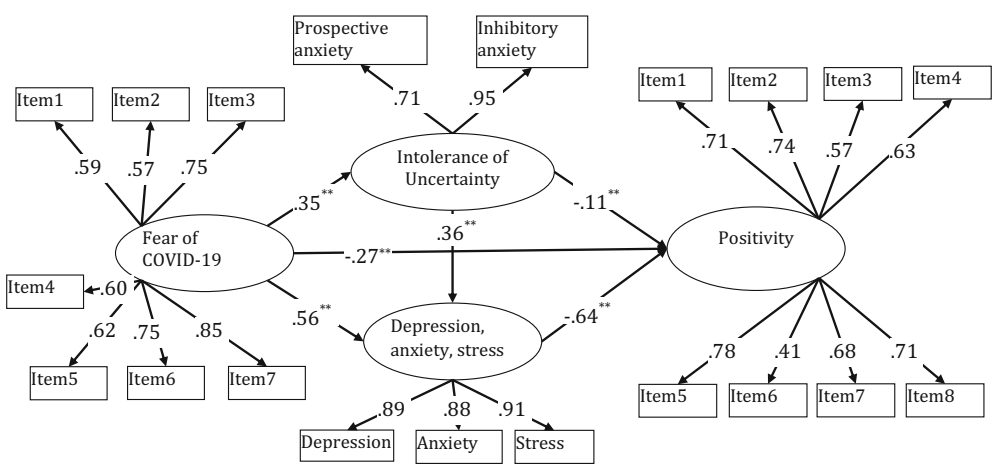

Fig. 2 Mediation model of the relationships between the research variables

\section{Discussion}

Among the findings of this research, first, the relationship between descriptive variables and the fear of COVID-19 was examined. According to the findings, the fear of COVID-19 was significantly higher in females compared to males and in individuals with chronic illnesses compared to those with no chronic illnesses at all. The gender difference in the fear of COVID19 was consistent with the finding that the coronavirus pandemic causes more psychological effects in females (Wang et al. 2020) and findings of previous studies on mental health in women (Lim et al. 2018). Gender is one of the factors that affect the health and disease status of individuals (Eryiğit Günler 2011). Generally, women adapt better to environmental stress factors and live longer; however, they are typically physically weaker and become ill more often (Overfield 2018). Getting sick more frequently may have contributed to higher levels of the fear of COVID-19 in females compared to males. On the other hand, gender roles are another factor that may be effective in this finding. Since women are perceived to be more vulnerable, weak, and delicate, it is culturally more acceptable for women to become ill and to express their illnesses, complaints, and fears about the disease more easily. On the other hand, the role of the male gender emphasizes strength, bravery, and fearlessness. Longer hospital stays among males (Overfield 2018) can be considered as an indicator of this situation. Avoiding asking for help until their illness gets serious can lead to delays, thereby prolonging

Table 3 Bootstrapping analysis results of the model

\begin{tabular}{|c|c|c|c|}
\hline Pathway & Coefficient & Lower bound & Upper bound \\
\hline \multicolumn{4}{|l|}{ Direct effect } \\
\hline Fear of COVID-19 $\rightarrow$ DAS & .56 & .50 & .62 \\
\hline Fear of COVID-19 $\rightarrow$ Intolerance of Uncertainty & .35 & .28 & .43 \\
\hline Fear of COVID-19 $\rightarrow$ Positivity & -.27 & -.35 & -.19 \\
\hline DAS $\rightarrow$ Positivity & -.64 & -.76 & -.54 \\
\hline Intolerance of Uncertainty $\rightarrow$ DAS & .36 & .30 & .42 \\
\hline Intolerance of Uncertainty $\rightarrow$ Positivity & -.11 & -.20 & -.02 \\
\hline \multicolumn{4}{|l|}{ Indirect effect } \\
\hline Intolerance of Uncertainty $\rightarrow$ DAS $\rightarrow$ Positivity & -.23 & -.29 & -.18 \\
\hline COVID-19 $\rightarrow$ Intolerance of Uncertainty $\rightarrow$ DAS & .13 & .09 & .16 \\
\hline COVID-19 $\rightarrow$ Intolerance of Uncertainty $\rightarrow$ DAS $\rightarrow$ Positivity & -.48 & -.57 & -.41 \\
\hline
\end{tabular}


the treatment process. Therefore, men may be less afraid of COVID-19 because they get sick less frequently than women except for chronic illnesses, or they may avoid expressing their fears due to gender roles.

High levels of fear of COVID-19 in individuals with chronic diseases can be considered as an expected finding because, throughout the process, all sources of information have emphasized that COVID-19 affects people with chronic health problems more. Additionally, having one or more chronic health problems besides COVID-19 has been stated to increase the rate of mortality. Information of this kind may naturally have played a role in increasing the levels of the fear of COVID-19 of those who have chronic health problems.

Other findings of the study indicated that the relationships between all the variables discussed were significant and the mediation model employed in the study model was confirmed. Findings obtained from the model revealed that the fear of COVID-19 predicted positivity both directly and through intolerance of uncertainty, depression, anxiety, and stress. The findings obtained were similar to the findings of other studies on the COVID-19 outbreak and its psychological effects. For example, in a study conducted by Satici et al. (2020b), a positive relationship was found between the fear of COVID-19 and intolerance of uncertainty. In the same study, a negative relationship was found between the fear of COVID-19 and mental well-being, which may be associated with positivity. Another study (Satici et al. 2020a) found a negative relationship between fear of COVID-19 and life satisfaction (which is another concept associated with positivity). At the same time, there were positive correlations between fear of COVID-19 and depression, anxiety, and stress in this study. In addition, depression, anxiety, and stress had a mediating role between fear of COVID-19 and life satisfaction. In the study of Harper et al. (2020), positive relationships were found between depression, anxiety, and fear of COVID-19. Another study on the psychological effects of COVID-19 in China, (Wang et al. 2020) found that more than half of the respondents rated their psychological symptoms as moderate to severe and that about one-third of them reported moderate to severe anxiety. Additionally, in their study handling quantitative and qualitative data interactively, Nicomedes and Avila (2020) conceptualized a COVID-19 panic framework and listed the themes from negative to positive in the following way: indifference, destruction, nihilism, paranoia, sadness, fear, the transmission of the virus, shock, blaming the state, anxiety, anxiety about past pandemics, anxiety about self/family/others, transfer of knowledge, compliance, appropriateness, protection, attention, optimism, and health awareness.

COVID-19, which is highly infectious, has caused a serious pandemic. Because there is no vaccine or drug developed against the disease, many countries have depleted their medical resources and the number of people who get sick and die due to the disease is increasing every day. Experts cannot predict when the fight against the disease will be successful and when/to what extent life will return to "normal", and this is causing uncertainty. Fear is a strong emotion that affects individuals' physical responses, cognitive skills, and moods. Increased severity of fear plays a role in increasing intolerance of uncertainty. Increased intolerance of uncertainty, on the other hand, seems to affect positivity levels negatively. In brief, a negative emotion triggers other negativity and further aggravates the situation (Satici et al. 2020b).

Findings showing that the fear of COVID-19 predicts depression, anxiety, and stress are not surprising. High levels of fear of COVID-19 infection, which has much higher infectiousness and many more negative consequences compared with other viral respiratory diseases, seem to increase depression, anxiety, and stress responses. Increased depression, anxiety, and stress affect the positivity of individuals adversely. On the other hand, the situation in question may be thought to lead to a cycle; decreased positivity may increase fear of COVID-19; increased 
fear may increase levels of intolerance of uncertainty, depression, anxiety, and stress (Harper et al. 2020; Satici et al. 2020a; Taylor et al. 2020).

Positive psychology is a relatively new field, but its domain is expanding every day. An increasing number of experts are expressing the importance of considering both the positive and negative aspects of an experience in understanding health, which also includes positive cognitions. The absence of positivity is different from the presence of negativity and can be equally important (Wood and Johnson 2016). There is also a lot of evidence showing that positive experiences and positive cognitions are important for mental health. For example, as a result of the meta-analysis study in which Lyubomirsky et al. (2005) discussed the relationship of being positive with concepts such as optimism, happiness, and satisfaction with life, positive perspective is reported to bring success in many areas such as business performance, social relationship, perception of self and others, sociability, activity, coping, problem-solving, creativity, and health.

\section{Limitations}

The present study had some limitations. Since data were collected from participants on a voluntary basis through an online application, it would be necessary to be cautious about making some generalizations. It is also possible that the data may contain some bias (such as social acceptance error) since they are based on the personal statements of participants. We recommend that future studies should be conducted on different samples using different methods. This study used a crosssectional design. Although the structural equation model was employed in the study, the results obtained did not express the exact causal relationships between the variables.

\section{Conclusion}

The present study revealed that intolerance of uncertainty, depression, anxiety, and stress had a mediating role in the relationship between the fear of COVID-19 and positivity. The findings obtained in this study can be said to be important for intervention programs and support strategies to be developed during the COVID-19 pandemic to protect mental health and increase psychological resilience. These interventions can be applied primarily in risk groups (such as those with chronic conditions and older age) and online. Additionally, it can be thought that if individuals spend their time in environments where they feel safe during the pandemic, it will help them maintain their psychological health. In this context, instead of constantly following the news about the pandemic, it seems important to resort to activities for preventive mental health, such as performing family responsibilities, taking time for relaxing, and engaging in hobbies.

\section{Compliance with Ethical Standards}

Conflict of Interest The authors declare that they have no conflict of interest. Sources of funding are acknowledged.

Ethical Approval All procedures in this study involving human participants were conducted in accordance with the ethical standards of the Research Ethics Board of the University and the 1975 Helsinki Declaration.

Informed Consent Informed consent was obtained from all participants. 


\section{References}

Ahaber (2020). Kütahya'da korkunç olay! Koronavirüs (Covid-19) korkusu sebebiyle intihar etti. Retrieved 12 April 2020 from: https:/www.ahaber.com.tr/yasam/2020/03/31/kutahyada-korkunc-olay-koronaviruscovid-19-korkusu-sebebiyle-intihar-etti.

Ahorsu, D.K., Lin, C-Y., Imani, V., Saffari, M., Griffiths, M. D., \& Pakpour, A. H. (2020). The Fear of COVID19 Scale: Development and initial validation. International Journal of Mental Health and Addiction. https://doi.org/10.1007/s11469-020-00270-8.

APA. (2013). DSM-5. Washington: American Psychiatric.

BBC (2020). Koronavirüs - Los Angeles Times: Salgın büyürken Amerikalılar silah depoluyor. Retrieved 12 April 2020 from: https:/www.bbc.com/turkce/haberler-dunya-51908443.

Beidel, D. C., Bulik, C. M., \& Stanley, M. A. (2014). Abnormal psychology. Boston: Pearson.

Buhr, K., \& Dugas, M. J. (2002). The intolerance of uncertainty scale: Psychometric properties of the English version. Behavior Research and Therapy, 40(8), 931-946. https://doi.org/10.1016/s0005-7967(01)00092-4.

Caprara, G. V., Alessandri, G., Trommsdorff, G., Heikamp, T., Yamaguchi, S., \& Suzuki, F. (2012). Positive orientation across countries. Journal of Cross-Cultural Psychology, 43(1), 77-83 https://doi.org/10.1177 $/ 0022022111422257$.

Carleton, R. N., Sharpe, D., \& Asmundson, G. J. G. (2007). Anxiety sensivity and intolerance of uncertainity: Requisites of the fundamental fears? Behavior Research and Therapy, 45, 2307-2316 https://doi. org/10.1016/j.brat.2007.04.006.

Çıkrıkçı, Ö., Çiftçi, M., \& Gençdoğan, B. (2015). Pozitiflik Ölçeği Türkçe Formu’nun psikometrik özellikleri. The Journal of Happiness \& Well-Being, 3(1), 57-76.

Diener, E., Suh, E., Lucas, R. E., \& Smith, H. L. (1999). Subjective well-being: Three decades of progress. Psychological Bulletin, 125(2), 276-302 https://doi.org/10.1037/0033-2909.125.2.276.

Dozois, D. J. A., \& Rnic, K. (2019). Abnormal psychology perspectives. D. J. A. Dozois (Ed.), pp. 48-61, Toronto: Pearson.

Dozois, D. J. A., Wilde, J. L., \& Frewen, P. A. (2019). In D. J. A. Dozois (Ed.), Abnormal psychology perspectives (pp. 95-125). Pearson.

Dugas, M. J., Gosselin, P., \& Ladouceur, R. (2001). Intolerance of uncertainty and worry: Investigating narrow specificity in a non-clinical sample. Cognitive Theraphy and Research, 25, 551-558.

Efilti, E. (2018). In S. Avșaroğlu (Ed.), Çocuk ve Ergenlerde Gelişimsel ve Davranışsal Bozukluklar (pp. 79-97). Ankara: Vize Akademik.

Eryiğit Günler, O. (2011). Hemodiyaliz Hastalarında Hastalı̆̆a Bağll Toplumsal Rol Değişimi Beklenti ve Sorunlart: Bir Sağlık Sosyolojisi Çalışmast. Unpublished master's thesis. Konya: Selçuk Üniversitesi, Sosyoloji Anabilim Dalı.

Euronews. (2020a). Fransa: Reims futbol kulübünün doktoru koronavirüs nedeniyle intihar etti. Retrieved 12 April 2020 from: https://tr.euronews.com/2020/04/06/fransa-reims-futbol-kulubunun-doktoru-koronavirusnedeniyle-intihar-etti.

Euronews (2020b). Koronavirüse yakalandığını düșünen çift intihar etti. Retrieved 12 April 2020 from: https://tr. euronews.com/2020/04/07/koronaviruse-yakalandigini-dusunen-cift-intihar-etti.

Fredrickson, B. (2009). Positivity: Groundbreaking research reveals how to embrace the hidden strength of positive emotions, overcome negativity, and thrive. New York: Random House.

Harper, C. A., Satchell, L. P., Fido, D., \& Latzman, R. D. (2020). Functional fear predicts public health compliance in the COVID-19 pandemic. International Journal of Mental Health Addiction. https://oi. org/10.1007/s11469-020-00281-5.

Hooley, J. M., Butcher, J. N., Matthew, K. N., \& Mineka, S. (2016). Abnormal psychology. Boston: Pearson.

Hu, L. T., \& Bentler, P. M. (1999). Cutoff criteria for fit indexes in covariance structure analysis: Conventional criteria versus new alternatives. Structural Equation Modeling: A Multidisciplinary Journal, 6(1), 1-55. https://doi.org/10.1080/10705519909540118.

Huang, Y., \& Zhao, N. (2020, 2020). Generalized anxiety disorder, depressive symptoms and sleep quality during COVID-19 epidemic in China: A web-based cross-sectional survey. MedRxiv Preprint https://oi. org/10.1101/2020.02.19.20025395.

Lim, G. Y., et al. (2018). Prevalence of depression in the community from 30 countries between 1994 and 2014. Scientific Reports, 8(1), 28-61. https://doi.org/10.1038/s41598-018-21243-x.

Lovibond, P. F., \& Lovibond, S. H. (1995). The structure of negative emotional states: Comparison of the depression anxiety stress scales (DASS) with the Beck depression and anxiety inventories. Behaviour Research and Therapy, 33(3), 335-343. https://doi.org/10.1016/0005-7967(94)00075-u.

Lu, H., Nie, P., \& Qian, L. (2020). Do quarantine experiences and attitudes towards COVID-19 affect the distribution of psychological outcomes in China? A quantile regression analysis, GLO Discussion Paper, No. 512. Essen: Global Labor Organization (GLO). 
Lyubomirsky, S., King, L., \& Diener, E. (2005). The benefits of frequent positive affect: Does happiness lead to success? Psychological Bulletin, 131(6), 803-855. https://doi.org/10.1037/0033-2909.131.6.803.

MacLeod, A. K., \& Moore, R. (2000). Positive thinking revisited: Positive cognitions, well-being, and mental health. Clinical Psychology \& Psychotherapy: An International Journal of Theory \& Practice, 7(1), 1-10. https://doi.org/10.1002/(SICI)1099-0879(200002)7:1\%3C1::AID-CPP228\%3E3.0.CO;2-S.

Maslow, A. H. (1954). Motivation and personality. New York: Harper.

McGrath, P. (2004). The burden of RA RA positive: Survivors' and hospice patients' reflection on maintaining a positive attitude to serious illness. Support Care Cancer, 12, 25-33. https://doi.org/10.1007/s00520-0030547-4.

Naragon, K., \& Watson, D. (2009). In S. J. Lopez (Ed.), The encyclopedia of positive psychology (pp. 707-711). Malden: Wiley Blackwell.

Nicomedes, C. J. C., \& Avila, R. M. A. (2020). An analysis on the panic of Filipinos during COVID-19 pandemic in the Philippines. Retrieved 19 April 192020 from: https://www.researchgate. net/profile/Christian_Jasper_Nicomedes/publication/340081049_An_Analysis_on_the_Panic_of_Filipinos

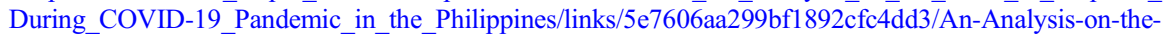
Panic-of-Filipinos-During-COVID-19-Pandemic-in-the-Philippines.pdf.

Nolen-Hoeksema, S. (2014). Abnormal psychology. Yale: McGraw Hill.

Overfield, T. (2018). Biological variation in health and illness: Race, age, and sex. Boca Raton: CRC Press.

Pakpour, A. H., \& Griffiths, M. D. (2020). The fear of COVID-19 and its role in preventive behaviors. Journal of Concurrent Disorders, 2(1), 58-63.

Reznik, A., Gritsenko, V., Konstantinov, V., Khamenka, N., \& Isralowitz, R. (2020). COVID-19 fear in Eastern Europe: Validation of the fear of COVID-19 scale. International Journal of Mental Health and Addiction. https://doi.org/10.1007/s11469-020-00283-3.

Preacher, K. J., \& Hayes, A. F. (2008). Assessing mediation in communication research. The Sage sourcebook of advanced data analysis methods for communication research, 13-54.

Sakib, N., Mamun, M. A., Bhuiyan, A. K. M. I., Hossain, S., Mamun, F. A., Hosen, I., et al. (2020). Psychometric validation of the Bangla fear of COVID-19 scale: Confirmatory factor analysis and Rasch analysis. International Journal of Mental Health and Addiction. https://doi.org/10.1007/s11469-020-00289$\mathrm{x}$.

Sarıçam, H. (2018). The psychometric properties of Turkish version of depression anxiety stress Scale-21 (DASS-21) in health control and clinical samples. Journal of Cognitive Behavioral Psychotherapy and Research, 7(1), 19-30.

Sarıçam, H., Erguvan, F. M., Akın, A., \& Akça, M. S. (2014). The Turkish short version of the intolerance of uncertainty (IUS-12) scale: The study of validity and reliability. Route Educational and Social Science Journal, 1(3), 148-157. https://doi.org/10.17121/ressjournal.109.

Satici, B., Gocet-Tekin, E., Deniz, M. E., \& Satici, S. A. (2020a). Adaptation of the fear of COVID-19 scale: Its association with psychological distress and life satisfaction in Turkey. International Journal of Mental Health Addiction. https://doi.org/10.1007/s11469-020-00294-0.

Satici, B., Saricali, M., Satici, S.A., \& Griffiths, M.D. (2020b). Intolerance of uncertainty and mental wellbeing: Serial mediation by rumination and fear of COVID-19. International Journal of Mental Health and Addiction. https://doi.org/10.1007/s11469-020-00305-0.

Scheier, M. F., \& Carver, C. S. (1993). On the power of positive thinking: The benefits of being optimistic. Current Directions in Psychological Science, 2(1), 26-30. https://doi.org/10.1111/1467-8721.ep10770572.

Scheier, M. F., \& Carver, C. S. (1992). Effects of optimism on psychological and physical wellbeing: Theoretical overview and empirical update. Cognitive Therapy and Research, 16, 201-228. https://doi.org/10.1007 /BF01173489.

Seligman, M. E. P., \& Csikszentmihalyi, M. (2000). Positive psychology: An introduction. American Psychologist, 55(1), 5-14. https://doi.org/10.1037/0003-066X.55.1.5.

Soraci, P., Ferrari, A., Abbiati, F. A., Del Fante, E., De Pace, R., Urso, A., \& Griffiths, M. D. (2020). Validation and psychometric evaluation of the Italian version of the fear of COVID-19 scale. International Journal of Mental Health and Addiction. https://doi.org/10.1007/s11469-020-00277-1.

Tabachnick, B. G., \& Fidell, L. S. (2007). Using multivariate statistics. Boston: Pearson.

Taylor, B. (2006). Vaccines and the changing epidemiology of autism. Child Care and Health Development, 32, 11-19. https://doi.org/10.1111/j.1365-2214.2006.00655.x.

Taylor, S., Landry, C., Paluszek, M., Fergus, T. A., Mckay, D., \& Asmundson, G. J. G. (2020). Development and initial validation of the COVID stress scales. Journal of Anxiety Disorders. https://doi.org/10.1016/j. janxdis.2020.102232.

T. R. Ministry of Health (2020). Türkiye günlük koronavirüs tablosu. Retrieved 1 May 2020 from: https://covid19.saglik.gov.tr/. 
Wang, C., Pan, R., Wan, X., Tan, Y., Xu, L., Ho, C. S., et al. (2020). Immediate psychological responses and associated factors during the initial stage of the 2019 coronavirus disease (COVID-19) epidemic among the general population in China. International Journal of Environmental Research and Public Health, 17, 1729. https://doi.org/10.3390/ijerph17051729.

Wood, A. M., \& Johnson, J. (2016). The Wiley handbook of positive clinical psychology (pp. 1-18). Malden: Wiley Black.

World Health Organization (2020a). Q\&A on coronaviruses (COVID-19). Retrieved 12 April 2020 from: https://www.who.int/news-room/q-a-detail/q-a-coronaviruses\#: :text=symptoms.

World Health Organization (2020b). WHO Director-General's opening remarks at the media briefing on COVID-19 - 18 March 2020. Retrieved 12 April 2020 from: https://www.who.int/dg/speeches/detail/whodirector-general-s-opening-remarks-at-the-media-briefing-on-covid-19\%2D\%2D-18-march-2020.

World Health Organization (2020c). Report of the WHO-China Joint Mission on Coronavirus Disease 2019 (COVID-19). Retrieved 12 April 2020 from: https:/www.who.int/docs/default-source/coronaviruse/whochina-joint-mission-on-covid-19-final-report.pdf.

World Health Organization (2020d). WHO Director-General's opening remarks at the media briefing on COVID-19 - 3 March 2020. Retrieved 12 April 2020 from: https://www.who.int/dg/speeches/detail/whodirector-general-s-opening-remarks-at-the-media-briefing-on-covid-19\%2D\%2D-3-march-2020.

World Health Organization (1948). United Nations World Health Organization Interim Comission. Offical reports of the World Health Organization, No:2, New York. p.16.

WSWS (2020). Avrupa'da COVID-19 salgını stresi nedeniyle hemșire intiharları artıyor. Retrieved 12 April 2020 from: https://www.wsws.org/tr/articles/2020/04/03/trez-a03.html.

Yıldırım, A., Boysan, M., \& Kefeli, M. C. (2018). Psychometric properties of the Turkish version of the depression anxiety stress Scale-21 (DASS-21). British Journal of Guidance \& Counselling, 46(5), 582595. https://doi.org/10.1080/03069885.2018.1442558.

Yılmaz, Ö., Boz, H., \& Arslan, A. (2017). Depresyon Anksiyete Stres Ölçeğinin (DASS 21) Türkçe Kısa Formunun Geçerlilik-Güvenilirlik Çalıșması. Finans Ekonomi ve Sosyal Araştırmalar Dergisi, 2(2), $92-104$.

Publisher's Note Springer Nature remains neutral with regard to jurisdictional claims in published maps and institutional affiliations. 